\title{
Neuropeptides, intestinal immunological integrity and inflammatory bowel disease
}

\author{
ClifFord A OTtawAy, MD, PHD, FRCPC
}

\begin{abstract}
CA OTTAWAY. Neuropeptides, intestinal immunological integrity and inflammatory bowel disease. Can J Gastroenterol 1993;7(2):76-82. Although many aspects of immunoregulation are exerted through mechanisms that are autonomous to the immune system, it is established that complex and potent regulatory interactions link the nervous and immune systems in intact animals. The intestinal mucosa is a highly integrated organ which contains specialized subdivisions of both the nervous and immune systems and is expected, therefore, to be a specialized venue for neural-immune interactions. A principal means for this interaction is through the ability of lymphoid cells of the mucosa to recognize and respond to neuropeptide signals, such as the vasoactive intestinal peptide and substance $P$, released from local nerves. This report examines mechanisms by which neurophysiological regulation of the local activity and local accumulation of lymphoid cells can occur in the intestinal mucosa, and explores the pathophysiological implications of the pronounced disruptions of local nerves that occur in the mucosa of patients with IBD.
\end{abstract}

Key Words: Inflammatory Bowel Disease, Intestinal immunoregulation, Mucosal nerves, Neuropeptides, Substance P, Vasoactive intestinal peptide

\section{Neuropeptides, immunité immunologique intestinale et maladie intestinale inflammatoire}

RÉSUMÉ: Bien que divers aspects de l'immunorégulation soient gérés par des mécanismes autonomes du système immunitaire, des interactions régulatoires complexes et puissantes lient entre eux les systèmes nerveux et immunitaires chez les animaux sains. La muqueuse intestinale est un organe hautement intégré où agissent de concert le système nerveux et le système immunitaire; il s'y produit donc des interactions neuro-immunitaires spécialisées. Ces interactions surviennent surtout grâce à la capacité des cellules lymphoïdes de la muqueuse à reconnaître les signaux neuropeptidiques et à y répondre, qu'il s'agisse de peptide intestinal vasoactif ou de substance P libérée par les fibres nerveuses locales. Ce rapport se penche sur les mécanismes par lesquels la régulation neurophysiologique de l'activité locale et de l'accumulation localisée de cellules lymphoïdes peuvent se produire dans la muqueuse intestinale et explore les implications physiopathologiques des lésions des fibres nerveuses locales au niveau de la muqueuse des patients atteints de maladie intestinale inflammatoire.

Department of Medicine, St. Michael's Hospital, University of Toronto, Toronto, Ontario

Correspondence and reprints: CA Ottaway, Room 6360, Medical Sciences Bldg., University of Toronto, Toronto, Ontario, Canada, M5S 1A8. Telephone (416) 978-7188,

Fax (416) 978-8765
J THE PAST 10 YEARS, SUBSTANTIAL. levidence has emerged to support the general concept that a complex network of interactions occur between the central nervous system (CNS) and the immune system in mammals (1-3). The purposes of this report are twofold: first, to examine the concept that the intestinal mucosa is a specialized venue for interactions between the nervous and immune systems; and second, to explore the relevance of this to the pathophysiology of inflammatory bowel disease (IBD).

Although other neuropeptides also are likely to be involved (4), emphasis will be placed on the vasoactive intestinal peptide (VIP) and substance P, two enteric neuropeptides which are normally found in great abundance in the enteric nervous system (ENS). Three special features of the intestine warrant attention. First, lymphoid cells in the intestine function in microenvironments in which they are exposed to the neuropeptides VIP and substance P. Second, lymphoid cells express receptors for these signals. Third, interaction with these peptides modulates the behaviour of lymphoid cells in vitro and in vivo.

\section{THE INTESTINAL MUCOSA AS} A NEURAL-IMMUNE VENUE

The intestine contains specialized subdivisions of both the immune and nervous systems (Figure 1). There are three major lymphoid compartments in 
the intestine: aggregated gut-associated lymphoid tissues (GALT) such as Peyer's patches, appendix and tonsils; the lamina propria, and the epithelium. Each of these contains different lymphoid cell populations and has different opportunities to contact neuropeptides.

The aggregated GALT tissues form the principal immunological affector compartment of the intestine and act as antigen detectors and processors. Structurally, they have many similarities to lymph nodes, but they are at the gut surface and have an overlying epithelium which is specialized for the sampling of intestinal lumen contents. Beneath this microfold-bearing epithelium, macrophages and dendritic cells are found that permit antigen presentation to lymphocytes (5). B cells are organized in the follicles that surround the $T$ cell and vascular corridors of these lymphoid compartments. GALT structures are the major sites at which the activation and programming of immunoglobulin (Ig) A-producing B cells and mucosally directed $\mathrm{T}$ effector cells are initiated, and the immune responses that occur in these compartments generate the precursors of the effector cells that migrate via the central circulation $(6,7)$ to populate the other two lymphoid compartments of the intestinal mucosa.

There is regional variation in the innervation of GALT tissues. For example, tonsils are innervated via the IX cranial nerve and branches of the pharyngeal and palantine nerves (8). The appendix of the rabbit is innervated by fibres derived from the mesenteric ganglia, and finely varicose nerve fibres branch throughout the internodular $\mathrm{T}$ cell dependent areas and surround the vasculature $(9,10)$. Similar innervation is found in rabbit Peyer's patches (11), and the density and pattern of innervation in these GALT tissues is similar to that found in regional lymph nodes $(10)$ where most of the innervation also is restricted to $\mathrm{T}$ cell corridors of the lymphoid organs. Neuropeptide-containing nerves have been identified in these organs, although they comprise only a minority

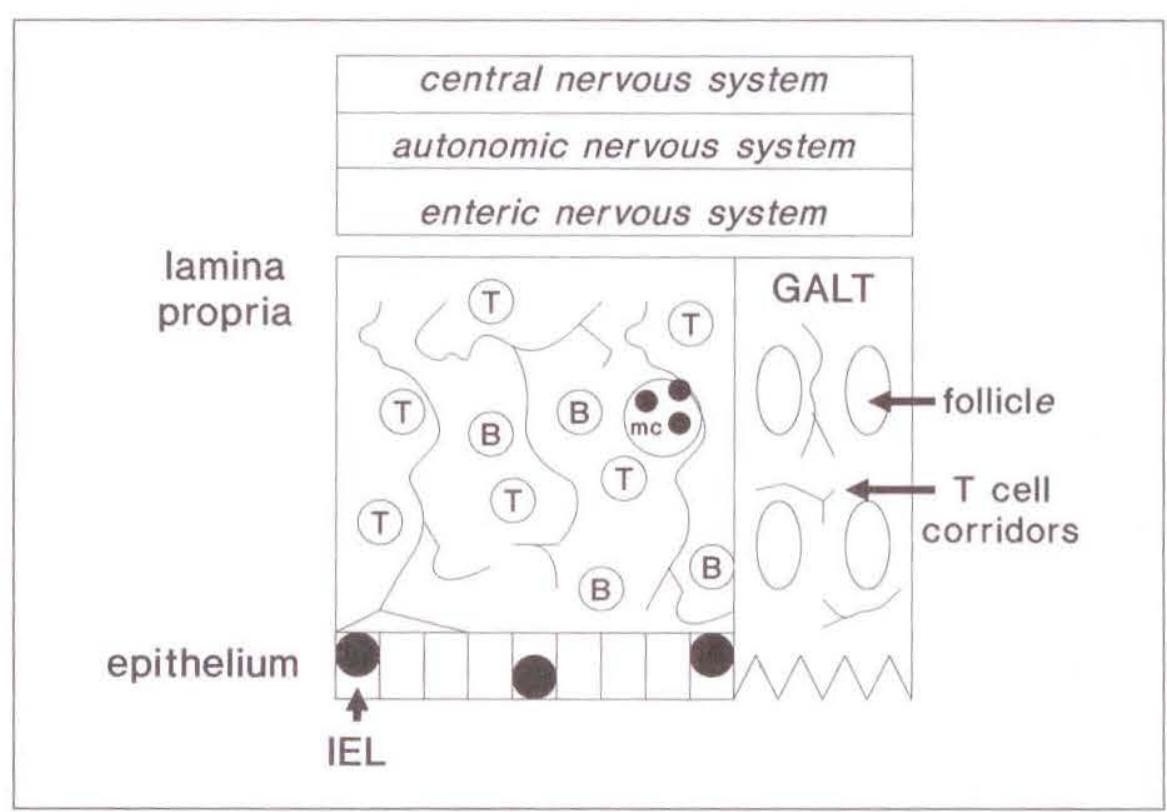

Figure 1) A schema of the immune compartments of the intestine and their innervation. The lamina propria consists of approximately $50 \%$ lymphoid cells. T cells, B cells and mucosal mast cells (mc) are represented. This compartment is innervated densely with peptidergic fibres arising from the submucosal plexus of the enteric nervous system. The epithelial layer contains intraepithelial lymphocytes (IEL). The organized gut-associated lymphoid tissues (GALT) contain recognizable B cell follicles and T cell corridors similar to lymph nodes. The GALT is less densely innervated with peptidergic fibres than is the lamina propria and is served by the enteric and/or autonomic nervous system depending upon the region of the gut tract where they are situated.

of the nerve population. In human tonsils, both substance $\mathrm{P}$-containing and VIP-containing nerve fibres have been identified along the vasculature, scattered throughout the $\mathrm{T}$ cell corridors and extending to beneath the epithelium (12). Within $\mathrm{T}$ cell regions, areas have been identified in which $T$ cells appear to be in close proximity to substance P-containing and VIP-containing fibres (12); these nerves have been identified in mesenteric lymph nodes of a number of species (13-15); and in murine Peyer's patches, nerve fibres enter the tissue in concert with the vasculature (a substantial number of these are VIP-containing nerve fibres) (16). Although less dense than those in adjacent portions of lamina propria, VIP-ergic nerves are prominent in the T cell corridors and some VIP-containing nerves come into close proximity to the specialized high endothelial post capillary venules through which $B$ and $T$ cells migrate into this tissue from the bloodstream $(6,16)$.

Large numbers of affector $T$ and $B$ lymphocytes are found within the lamina propria. Approximately $50 \%$ of this compartment consists of lymphoid cells (17). The lamina propria of the intestine receives a dense supply of nerve fibres, most of which arise from the intrinsic neurons of the ENS and much of which arises locally from the submucosal plexus (18). Although only a small proportion of the extrinsic nerves which serve the gut use neuropeptides (19), a significant minority of the neurons of the myenteric plexus (and most of those in the submucosal plexus) are peptidergic $(20,21)$. VIP-containing nerve fibres are the most prevalent nerves in the lamina propria. VIP nerves form dense networks of fibres around the epithelial crypts, and ramify throughout the tissue $(21,22)$. Substance $\mathrm{P}$-using fibres share a similar, though less dense, pattern in the lamina propria (20-22).

Conceptually it is important to consider how close a lymphoid cell must be to a nerve for a neuropeptide to affect the response of the lymphocyte. Direct lymphoid cell-nerve contacts may 
TABLE 1

Some effects of substance $\mathrm{P}$ and vasoactive intestinal peptide on lymphoid cell functions in vitro

\begin{tabular}{lcc}
\hline Modulates & Substance P & $\begin{array}{c}\text { Vasoactive intestinal } \\
\text { peptide }\end{array}$ \\
\hline Monocytes: & yes & yes \\
Chemotaxis & yes & $?$ \\
Interleukin-1 production & yes & yes \\
Respiratory burst & yes & $?$ \\
Lipid mediator & & \\
Lymphocytes: & & yes \\
Proliferation to: & yes & yes \\
T cell mitogens & $?$ & yes \\
Allogeneic stimulus & & yes \\
Production of: & yes & yes \\
Immunoglobulin & $?$ & yes \\
Interleukin-2 & $?$ & \\
Interleukin-5 & yes & \\
Cytotoxicity & & yes \\
Mast cells (MC): & & no \\
Stimulation of secretion: & yes & \\
Peritoneal MC & yes & \\
Lamina propria MC & &
\end{tabular}

occur under some circumstances, but it has also been argued that 'en passant' release of neuropeptides from the varicosities of nerve fibres in the mucosa may permit signalling of target cells over short distances (23). The opportunity for lymphoid cells to approach neuropeptides using nerves probably varies in different regions of the mucosa. For example, the densely innervated regions surrounding the base of crypts is the place at which capillaries form larger diameter post capillary venules, the vessels through which lymphocytes leave the bloodstream to enter the mucosa $(24,25)$. Lymphoid cells reaching the mucosa must migrate through this region to reach other sites and may have the opportunity to interact with VIP or substance $\mathrm{P}$ at this stage. The average linear density of mucosal nerves in human bowel is of the order of 2 $\mathrm{m} / \mathrm{mm}^{3}$ of tissue $(26,27)$. It has been calculated that the mean radial distance between lymphoid cells is approximately $6 \mu \mathrm{m}$ and that the distance between a lymphoid cell and a VIP. containing nerve is approximately 4 $\mu \mathrm{m}$ (27). Mast cells may have a special predilection for achieving close proximity with nerves. Studies of mucosal mast cells in rat jejunum show that about $5 \%$ of the mast cells have direct nerve contacts, approximately $30 \%$ of the mast cells are within $1 \mu \mathrm{m}$, and $90 \%$ are within $2 \mu \mathrm{m}$ of nerve fibres (28).

The 1ymphoid cells in the intraepithelial compartment are a specialized effector cell population that supports cytotoxic activity and expresses a variety of $T$ cell determinants in humans, mice and rats (29). Terminal portions of the VIP- and substance P. containing nerve fibres can be identified just beneath the basement membrane of the epithelium $(20,22)$ and may provide for local signalling of epithelial and intraepithelial cells.

\section{INTERACTIONS OF NEUROPEPTIDES WITH LYMPHOID CELLS IN VITRO}

Specific receptors for the neuropeptides substance P and VIP have been demonstrated on lymphoid cells of humans and experimental animals. Human circulating mononuclear cell preparations show specific binding of substance P and VIP (30-35), while lymphocytes isolated from the lamina propria of human colon demonstrate specific binding of VIP (36). An impor- tant feature that emerges from these studies is that the ability to bind neuropeptides varies within the major lymphocyte subsets. For example, the binding properties for VIP vary within different phentotypically and functionally defined subpopulations of lymphocytes, and only minority populations of CD4 T cells, CD8 T cells, B cells and large granular lymphocytes express the ability to bind this neuropeptide (33). Subset restriction also occurs with the binding of substance $\mathrm{P}$ to human $\mathrm{T}$ cell subpopulations (35). Some lymphocyte subpopulations, therefore, might be able to recognize only one of these neuropeptides, while some lymphocytes might not recognize either peptide, and there may be some cells that are able to recognize both substance $\mathrm{P}$ and VIP at the same time.

In mice, suspensions of lymphocytes from abdominal lymphoid tissues (spleen, mesenteric lymph nodes and Peyer's patches) have been shown to bind VIP (37) and substance P (38) specifically, and VIP receptors have been identified on lymphocytes from the murine intestinal mucosa (39). A feature that emerges from these studies is that there are regional tissue differences in lymphocyte binding properties for the neuropeptides, but the extent to which these tissue variations represent selective accumulation of lymphoid cells with particular receptor expressions or a response of cell receptors to signals from the local environment is unknown.

Both substance $\mathrm{P}$ and VIP have the ability to regulate a variety of important immunological functions in vitro (Table 1). Although a complete picture is not yet available, the observations certainly support the notion that these neuropeptides are potent modulators of major immunoregulatory pathways.

Substance $\mathrm{P}$ is a potent stimulus of human monocyte chemotaxis (40), affecting the production of interleukin (IL) 1 in response to endotoxin (41), and regulating the production of IL-6 and tumour necrosis factor (42). Substance $\mathrm{P}$ enhances the cellular respiratory burst of guinea pig macrophages, and their production of 
oxygen-free radicals and arachidonic acid metabolites (43). VIP also is a potent stimulator of the chemotaxis of human monocytes (44), but unlike substance $\mathrm{P}$, it inhibits the respiratory burst of stimulated peripheral blood monocytes (45).

The proliferative response of both human and murine lymphocytes to mitogenic stimulation is enhanced by substance P $(34,46)$. In concanavalin A-stimulated murine cultures, substance $\mathrm{P}$ augments Ig production and preferentially increases $\operatorname{IgA}$ production by cultures of Peyer's patch and spleen lymphocytes (46). With spleen cells from mice infected with Schistosoma mansoni, however, substance $\mathrm{P}$ specifically decreases $\mathrm{Ig}$ secretion by spontaneously activated individual B cells (47).

In mouse lymphocyte cultures, VIP inhibits the proliferative response of $T$ cells to mitogens $(37,46,48)$ and inhibits the proliferative response of mouse lymphocytes in mixed lymphocyte cultures (49). VIP suppresses the activation of CD4 T cells (50) and inhibits their production of IL-2 in concanavalin A-stimulated cultures (50). In such cultures, VIP also inhibits the production of IgA by Peyer's patch lymphocytes, but enhances $\operatorname{Ig} A$ production by cultures of spleen or mesenteric node lymphocytes (46). In cultures of $T$ cells from the intestinal mucosa of mice, VIP induces the release of IL-5 (39), a cytokine which promotes B cell development and differentiation.

Substance P stimulates histamine secretion by both peritoneal and lamina propria rat mast cells (51). In contrast, VIP is a secretagogue for peritoneal, but not intestinal, mucosa mast cells (51).

VIP inhibits the cytotoxic activity of peripheral blood lymphocytes in humans and mice (52-54). VIP also inhibits the cytotoxic capacity of lymphocytes from mouse spleen and mesenteric lymph nodes (54), but appears unable to modulate the cytotoxic activity of intraepithelial preparations (55). In contrast, the cytotoxic activity expressed by murine intraepithelial suspensions is enhanced in the presence of substance $P$, whereas that of spleen cells is not affected (56).

\section{EFFECTS OF NEUROPEPTIDES ON LYMPHOID CELLS IN VIVO}

In vitro observations suggest that substance $\mathrm{P}$ and VIP can influence the integrity of mucosal immune reactions in two principal ways: by direct stimulation or inhibition of the activity of individual lymphoid cells, and by modulation of the production or release of regulatory cytokines that control subsequent immune events. Another feature that contributes to the continued integrity of intestinal immunity is the ongoing replacement and remodelling of the cellular constituents of the intestinal lymphoid compartments which are sustained by lymphocyte migration. There are a number of mechanisms by which the nervous system can affect lymphocyte migration (57), and several studies support the concept that neuropeptides substance P and VIP influence the outcome of mucosal reactions by altering the distribution and retention of migrating lymphoid cells in particular compartments in vivo.

Infusion of substance $\mathrm{P}$ into mice by means of subcutaneous osmotic pumps has been shown to increase production of IgA by lymphocytes from Peyer's patches (58) and to alter the cytotoxic activity of IEL retrieved from the epithelium (55). Although only a small proportion of the infused substance $\mathrm{P}$ in these experiments would be expected to reach the CNS of the animals (59), infusion of substance $P$ directly into the intracerebral ventricles of rats increases the available number of $\mathrm{T}$ cells circulating in the bloodstream (60). Thus, a component of the effects of substance $\mathrm{P}$ infusion on the activity of lymphocytes in the intestinal compartments may be mediated by the redistribution of migrating cells.

In sheep, acute infusion of substance $\mathrm{P}$ into the afferent lymphatics of lymph nodes enhances the output of lymphocytes in the efferent nodal lymph (61), while in rats, regional intra-arterial injection of substance $P$ in the mesenteric vasculature increased the total output of lymphocytes in the abdominal duct lymph (62). In each of these studies, subset selectivity appears to be involved. In sheep, T cell output from the node particularly appeared to be enhanced (61), while in the rat studies, there was a marked increase in B cells in the lymph (62). Similar studies (61, 63) with VIP have shown that infusion into the afferent lymphatic of sheep lymph nodes decreases the efferent output of lymphocytes and, in particular, the output of CD4 $\mathrm{T}$ cells from the node, whereas administration of VIP into small branches of the mesenteric artery serving the intestine in rats decreases the output of CD4 T cells in the lymph draining the intestine (64).

Interference with the ability of lymphocytes to recognize VIP also affects migratory properties. A decrease in the expression of VIP receptors by murine $\mathrm{T}$ cells, brought about by in vitro exposure of the lymphocytes to the neuropeptide, decreases the efficiency with which $T$ cells subsequently migrate from the blood into Peyer's patches and mesenteric lymph nodes in intact recipients $(65,66)$. These abdominal lymphoid tissues have VIPcontaining nerves associated with the specialized endothelium of the post capillary venules across which bloodborne lymphocytes must migrate to reach these compartments (16).

The secretion of mucosal mast cells can be triggered through neural signalling in vivo in an intriguing way. In rats immunized to produce an IgE-dependent hypersensitivity state and subjected to repeated exposure to the antigen in the context of an audiovisual conditioning stimulus, the subsequent reexposure of the animals to the cognitive signal provokes the release of mucosal mast cell products in the intact animal (67); this reaction may be mediated through the interaction of the CNS with substance P-containing nerves within the mucosa (which the mast cells can associate with) $(28,55)$.

\section{RELEVANCE TO IBD}

A unifying hypothesis consistent with current information is that a number of pivotal cellular events involved in the integrity of intestinal mucosal immunity can be regulated by the 
neurophysiological signals substance $P$ and VIP. It is well established that the enteric nervous system is disrupted in both Crohn's disease and ulcerative colitis, and that these disruptions affect both VIP- and substance P-using nerves $(27,68-72)$.

Until recently, most of the studies of nerves in IBD-affected tissues have been restricted to qualitative observations suggesting nerve damage, necrosis, and regeneration. A systematic analysis that quantified Schwann cell markers and VIP-immunostaining, however, has demonstrated a profound reduction of the density of nerves in the bowel in Crohn's disease and ulcerative colitis (27). That study emphasizes the marked decrease in the nerve density of the lamina propria in IBD affected mucosa and its correlation with inflammation. In the presence of severe inflammation, the density of VIP-using nerves in the lamina propria was reduced by $90 \%$, and even in the absence of inflammation VIP, nerve density was only about $50 \%$ of that in control specimens (27).

It also has been reported that increased plasma concentrations of VIP may be a marker of disease activity and/or the progress of disease in patients with IBD (73). The damage to VIP-containing nerves in the lamina propria (and perhaps the increased

\section{REFERENCES}

1. Ader R, Cohen N, Felten D, eds. Psychoneuroimmunology II. New York: Academic Press, 1991.

2. Goetzl E, Spector NH, eds. Neuroimmune Networks: Physiology and Disease. New York: Alan R Liss, 1989.

3. O'Dorisio MS, Panerai A (eds). Neuropeptides and Immunopeptides: Messengers in a neuroimmune axis. Ann N Y Acad Sci 1990;594:1-501.

4. Ottaway CA. Neuroimmunomodulation in the intestinal mucosa. Gastroenterol Clin North Am 1991;20:511.

5. Ermack TH, Owen RL. Differential distribution of lymphocytes and accessory cells in mouse Peyer's patches. Anat Rec 1986;215:144.

6. Ottaway CA Migration of lymphocytes within the mucosal immune system. In: Targan S, Shanahan F, eds. Immunology and Immunopathology of the liver and gastrointestinal tract. concentrations of circulating VIP in patients with active disease) is probably a consequence of the inflammatory response in the mucosa and likely affects substance P-using nerves $(69,71,72)$. Under these circumstances, one would expect that the immunoregulatory effects normally exerted by substance P and VIP in the mucosa would be compromised severely, and that the loss of these neuropeptide-mediated influences on local lymphoid cell activity would play a role in perpetuating the immunological aspects of the pathophysiological response in the tissue. If alternate ways could be found of providing these local regulatory influences or ways in which to promote regeneration or protection of the enteric nerves, however, new modes of therapy for IBD might be possible. For example, the primary structure of the receptors for both substance $P$ and VIP have been identified $(74,75)$. The receptor molecules are both members of the heptahelical neurotransmitter family of proteins. The development of agents that could function in vivo as selective agonists or antagonists of these receptors on lymphoid cells in the intestine may offer, in the future, means by which aspects of local immunoregulatory balance could be restored in the disease-affected bowels of IBD patients.

New York: Igaku-Shoin, 1990:49.

7. Salmi M, Jalkanen S. Regulation of lymphocyte traffic to mucosa- associated lymphatic tissues. Gastroenterol Clin North Am 1991;20:495.

8. Bulloch K. Neuroanatomy of lymphoid tissue. In: Guillemin R, Cohn M, Melnechuk T, eds. Neural Modulation of Immunity. New York: Raven Press, 1985:111.

9. Felten D, Felten S, Carlson S, Olschowka J, Livnat S. Noradrenergic and peptidergic innervation of lymphoid tissues. J Immunol 1985; 135:755s.

10. Felten D, Overhage J, Felten S, Schmedtje J. Noradrenergic sympathetic innervations of lymphoid tissue in the rabbit appendix. Brain Res Bull 1981;7:595.

11. Jesseph J, Felten D. Noradrenergic innervation of the gut associated lymphoid tissue in the rabbit. Anat Rec 1984;208:81A.

12. Weihe E, Krekel J.

\section{CONCLUSIONS}

The intestinal mucosa is likely a specialized venue for neural-immune interactions in intact animals including humans. The three functional lymphoid compartments of the intestine contain networks of nerves, many of which use the neuropeptides substance $\mathrm{P}$ and VIP; and subpopulations of T cells, B cells, monocytic cells and mast cells can recognize and respond to these neurophysiological signals. Interaction of substance $\mathrm{P}$ and VIP with lymphoid cells has been implicated in the accumulation of lymphoid cells in particular compartments, the activation and responsiveness of the cells, and the production of immunoglobulins and interleukins. The diverse effects exerted by these neuropeptides on immune responses suggest that the ENS plays an important local role in maintaining the integrity of the intestinal immune system, and that disruption of this regulation may influence the pathophysiology of both Crohn's disease and ulcerative colitis. Further exploration of these processes is needed before the contribution of peptide-mediated neural-immune interactions to the natural history and fundamental biol. ogy of IBD can be fully understood, but future developments may offer new means of intervening therapeuti. cally in these diseases.

The neuroimmune connection in human tonsils. Brain Behav Immun 1991;5:41.

13. Bellinger $D$, Lorton $D$, Romano $T$, Olschowka J, Felten S, Felten D.

Neuropeptide innervation of lymphoid organs. Ann New York Acad Sci 1990;594:17.

14. Fink T, Weihe E. Multiple neuropeptides in nerves supplying mammalian lymph nodes: messenger candidates for sensory and autonomic neuroimmunomodulation. Neurosci Lett 1988;90:39

15. Popper P, Mantyh C, Vigna S, Maggio J, Mantyh P. The localization of sensory nerve fibres and receptor binding sites for sensory neuropeptides in canine mesenteric lymph nodes. Peptides 1988;9:257.

16. Ottaway C, Lewis D, Asa S. Vasoactive intestinal peptide containing nerves in Peyer's patches. Brain Behavior and Immunity 1987;1:148. 
17. Lee E, Schiller LR, Fordtran JS. Quantification of colonic lamina propria cells by means of a morphometric point-counting method. Gastroenterology 1988;94;409.

18. Goyal RK, Crist JR. Neurology of the gut. In: Sleisenger M, Fordtran J, eds. Gastrointestinal Disease:

Pathophysiology, Diagnosis and Management, 4 edn. Philadelphia: WB Saunders, 1989:21.

19. Lundberg J, Hokfelt T, Nilsson G et al. Peptide neurons in the vagus, splanchnic and sciatic nerves. Acta Physiol Scand 1978;104:499.

20. Schultzberg M, Hokfelt T, Nilsson G et al. Distribution of peptide and catecholamine containing nerves in the gastrointestinal tract of rat and guinea pig. Neuroscience 1980;5:689.

21. Furness J, Costa M.Types of nerves in the enteric nervous system. Neuroscience 1980;5:1.

22. Costa M, Furness J, Llewellyn-Smith I: Histochemistry of the enteric nervous system. In: Johnson L, ed. Physiology of the gastrointestinal tract, Second edition. New York: Raven Press, 1987:1.

23. Cooke H. Neurobiology of the intestinal mucosa. Gastroenterology 1986;90:1057.

24. Husband AJ. Kinetics of extravasation and redistribution of $\lg A$-specific antibody containing cells in the intestine. J Immunol 1982;128:1355.

25. Jeurissen S, Duijvestijn A, Sontag Y, Kraal G. Lymphocyte migration into lamina propria of the gut is mediated by specialized HEV-like blood vessels. Immunology 1987;62:273.

26. Ferri G, Wright N, Soimero L, Lako G, Polak J. Quantification of the intestinal peptide-containing innervation. J Histochem Cytochem 1984:32:737.

27. Kubota Y, Petras RE, Ottaway CA, Tubbs RR, Farmer RG, Fiocchi C. Colonic vasoactive intestinal peptide nerves in inflammatory bowel disease. Gastroenterology 1992;102:1242.

28. Stead R, Tomioka M, Quinonez G, Simon G, Felten S, Bienenstock ]. Intestinal mucosal mast cells in normal and nematode infected rat intestines are in intimate contact with peptidergic nerves. Proc Natl Acad Sci USA 1987;84:2975.

29. Cerf-Bensussan N, Guy-Grand D. Intestinal intraepithelial lymphocytes. Gastroenterol Clin N A 1991;20:549.

30. Guerrero J, Prieto J, Elorza F, Ramirez R, Goberna R. Interactions of vasoactive intestinal peptide with human blood mononuclear cells. Mol Cell Endocrinol 1981;21:151.

31. Danek A, O'Dorisio M, O'Dorisio T, George J. Specific binding sites for vasoactive intestinal polypeptide on nonadherent peripheral blood lymphocytes. J Immunol 1983;131:1173.

32. Ottaway C, Bernaerts C, Chan B, Greenberg G. Specific binding of vasoactive intestinal peptide to human circulating mononuclear cells. Can J Physiol Pharmacol 1983;61:664.

33. Ottaway CA, Lay T, Greenberg G. High affinity specific binding of vasoactive intestinal peptide to human circulating T cells, B cells and large granular lymphocytes.

J Neuroimmunol 1990;29:149.

34. Payan D, Brewster D, Goetzl E. Specific stimulation of human T lymphocytes by substance $P$. J Immunol 1983;131:1613.

35. Payan D, Brewster D, Missirian-Bastian A, Goetzl E. Substance $P$ recognition by a subset of human $\mathrm{T}$ lymphocytes. J Clin Invest 1984;74:1532.

36. Pallone F, Fais S, Annibale M et al: Modulatory effects of somatostatin and vasoactive intestinal peptide on human intestinal lymphocytes. Ann N Y Acad Sci 1990;594:408.

37. Ottaway C, Greenberg G. Interaction of vasoactive intestinal peptide with mouse lymphocytes: Specific binding and modulation of mitogen responses. J Immunol 1984;132:417.

38. Stanisz A, Scicchitano R, Dazin P, Bienenstock J, Payan D. Distribution of substance $P$ receptors on murine spleen and Peyer's patch $T$ and B cells. J Immunol 1987;139:749.

39. Weinstock JW. Production of neuropeptides by inflammatory cells within the granulomas of murine schistosomiasis mansoni. Eur J Clin Investig 1991;21:145.

40. Ruff M, Wahl S, Pert C. Substance P receptor mediated chemotaxis of human monocytes. Peptides 1985;6:107.

41. Laurenzi M, Persson M, Dalsgaard, Haegerstrand A. Substance P stimulates the production of interleukin-1 in human blood monocutes. Scand I Immunol 1990;31:529.

42. McGillis ], Mitsuhashi M, Payan D. Immunomodulation by tachykinin neuropeptides. Ann N Y Acad Sci 1990;594:85.

43. Hartung $\mathrm{H}$, Toyka $\mathrm{K}$. Activation of macrophages by substance P: Induction of oxidative burst and thromboxane release. Eur J Pharmacol. 1983;89:301.

44. Sacerdote P, Ruff M, Pert C. VIPl-12 is a ligand for the CD4/Human immunodeficiency virus receptor. Ann N Y Acad Sci 1988:527:574.

45. Wiik P. Vasoactive intestinal peptide inhibits the respiratory burst in human monocytes by a cyclic AMP-mediated mechanism. Regul Pept 1989;25:187.
46. Stanisz A, Befus D, Bienenstock J: Differential effects of vasoactive intestinal peptide, substance $P$ and somatostatin on immunoglobulin synthesis and proliferation by lymphocytes from Peyer's patches, mesenteric lymph nodes and spleen. J Immunol 1986;136:152.

47. Neil GA, Blum A, Weinstock JV. Substance $P$ but not vasoactive intestinal peptide modulates immunoglobulin secretion in murine Schistosomiasis. Cellular Immunol 1991;135:394.

48. Kroc C, Gores A, Go V. Gastrointestinal regulatory peptides modulate in vitro immune reactions of mouse lymphocytes. Clin Immunol Immunopath 1986:39:308.

49. Kroc C, Gores A, Go V. Gastrointestinal regulatory peptides modulate mouse lymphocyte functions under serum free conditions in vitro. Immunol Invest 1986;15:103.

50. Ottaway CA. Selective effects of vasoactive intestinal peptide on the mitogenic response of murine T cells. Immunology 1987;62:291.

51. Shanahan F, Denburg J, Fox J, Bienenstock J, Befus D. Mast cell heterogeneity: Effects of neuroenteric peptides on histamine release. J Immunol 1985:135:1331.

52. Drew P, Shearman D. Vasoactive intestinal peptide: A neurotransmitter which reduces human NK cell activity and increases Ig synthesis. Aust J Exp Biol Med Sci 1985;63:313.

53. Rola-Pleszczynski M, Bolduc D, St. Pierre S. The effects of vasoactive intestinal peptide on human natural killer cell function. J Immunol 1985;135:350.

54. Yiangou Y, Serrano R, Bloom S, Pena J, Festenstein H. Effects of prepro-vasoactive intestinal peptide-derived peptides on the murine immune response.

J Neuroimmunol 1990;29:65.

55. Stead RH, Tomioka M, Pezzati P et al. Interaction of the mucosal immune and peripheral nervous systems. In: Ader R, Cohen N, Felten D, eds. Psychneuroimmunology II. New York: Academic Press, 1991:177.

56. Croitoru K, Ernst P, Bienenstock ], Padol 1, Stanisz A. Selective modulation of the natural killer activity of murine intestinal epithelial leukocytes by the neuropeptide substance P. Immunology 1990;71:196.

57. Ottaway CA, Husband AJ. Central nervous system influences on lymphocyte migration. Brain Behav Immun 1992:6:97.

58. Scicchitano R, Bienenstock J, Stanisz A. In vivo immunomodulation by the neuropeptide substance P. Immunology 
1988;63:733.

59. Aronin N, Difiglia M, Leeman SE. Substance P. In: Krieger D, Brownstein M, Martin J, eds. Brain Peptides. New York: Wiley-Interscience, 1983:783.

60. Fannon LD, Phillips MI. Chronic ICV infusion of neuropeptides alters lymphocyte populations in experimental rodents. Regul Peptides 1991;34:189.

61. Moore T. Modification of lymphocyte traffic by vasoactive neurotransmitter substances. Immunology 1984; 52:511.

62. Sharkey KA, Kirk DR, Graham TL. Substance P and CGRP modify lymphocyte output from the mesenteric lymphatic duct of the rat. Gastroenterology 1992;102:A759.

63. Moore T, Spruck C, Said S. Depression of lymphocyte traffic in sheep by vasoactive intestinal peptide. Immunology 1988;64:475.

64. Miura S, Ohkudo N, Imaeda $\mathrm{H}$ et al. VIP inhibits lymphocyte transportation in intestinal lymph from rat small intestine. Gastroenterology 1992;102:A746.

65. Ottaway CA. In vitro alteration of receptors for vasoactive intestinal peptide changes the in vivo localization of mouse T cells. J Exp Med 1984:160:1054.

66. Ottaway CA. Evidence for local neuromodulation of $\mathrm{T}$ cell migration in vivo. Adv Exp Med Biol 1985;186:637.

67. MacQueen G, Marshall J, Perdue M, Seigel S, Bienenstock J. Pavlovian conditioning of rat mucosal mast cells to secrete rat mast cell protease II. Science 1989;243:83.

68. Bishop A, Polak J, Bryant M, Bloom S, Hamilton S. Abnormalities of vasoactive intestinal polypeptide-containing nerves in Crohn's disease. Gastroenterology 1980;79:853.

69. Koch T, Carney J, Go VLW. Distribution and quantitation of gut neuropeptides in normal and inflammatory bowel disease. Dig Dis Sci 1987;32:369.

70. O'Morain C, Bishop A, McGregor G et al. Vasoactive intestinal peptide concentrations and immunocytochemical studies in rectal biopsies from patients with inflammatory bowel disease. Gut 1984;25:57.
71. Sjolund K, Schaffalitzky de Muckadell O, Fahrenkrug ], Hakanson R, Peterson B, Sundler F. Peptide-containing nerve fibres in the gut wall in Crohn's disease. Gut 1983;24:724.

72. Mazumdar S, Das KM. Immunocytochemical localization of vasoactive intestinal peptide and substance $\mathrm{P}$ in the colon from normal subjects and patients with inflammatory bowel disease. Am J Gastroenterol 1992;87:176.

73. Duffy LC, Zielezny M, Riepenhoff-Talty M, et al. Vasoactive intestinal peptide as a laboratory supplement to clinical activity index in inflammatory bowel disease. Dig Dis Sci 1989;34:1528.

74. Yokota Y, Sasai Y, Tanaka K. Fujiwara T. Molecular characterization of a functional CDNA for rat substance P receptor. J Biol Chem 1989;264:17649.

75. Sreedharan SP, Robichon A, Peterson KE, Goetzl E]. Cloning and expression of the human vasoactive intestinal peptide receptor. Proc Nat! Acad Sci USA 1991;88:4986. 


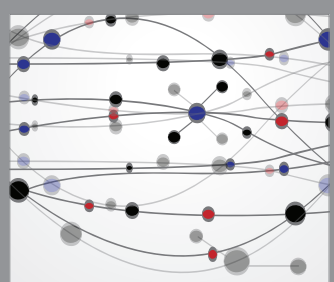

The Scientific World Journal
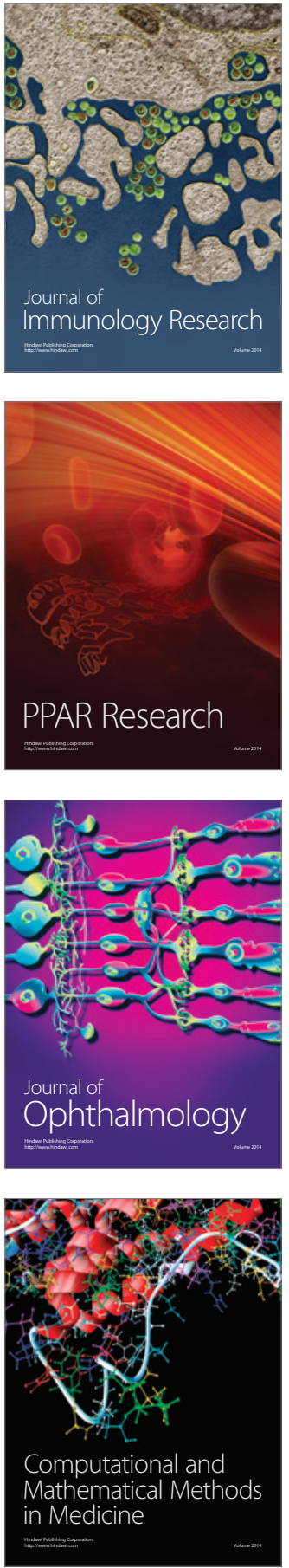

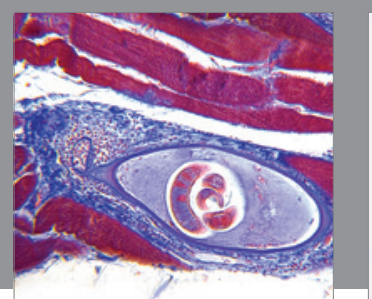

Gastroenterology Research and Practice

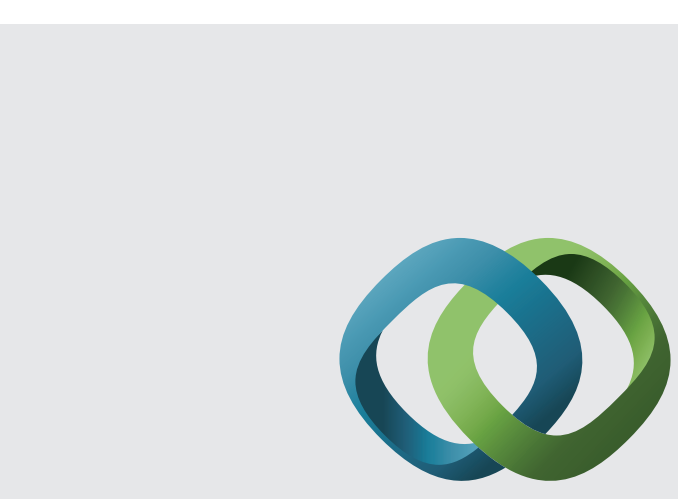

\section{Hindawi}

Submit your manuscripts at

http://www.hindawi.com
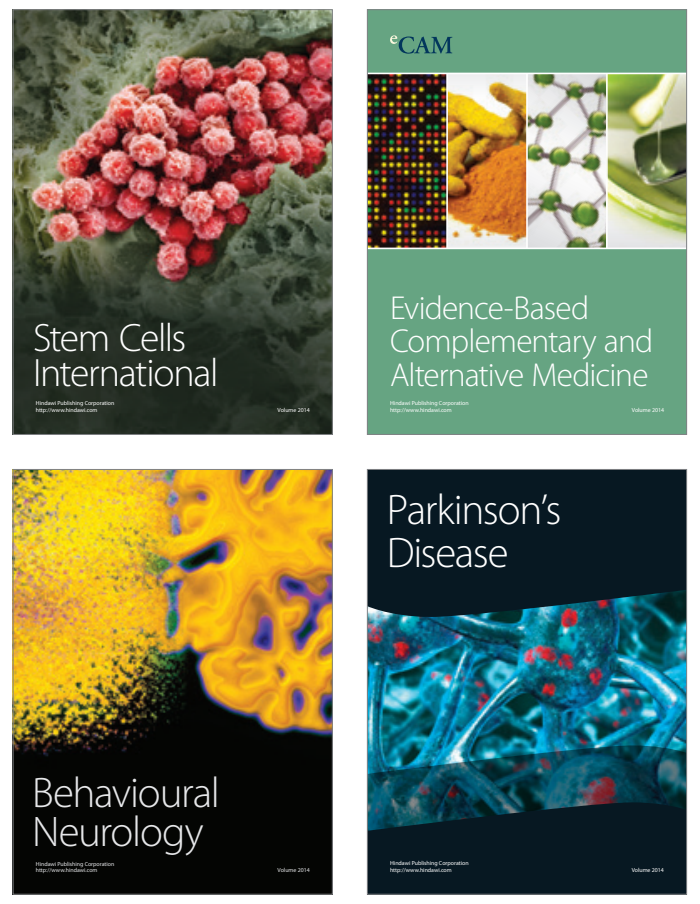
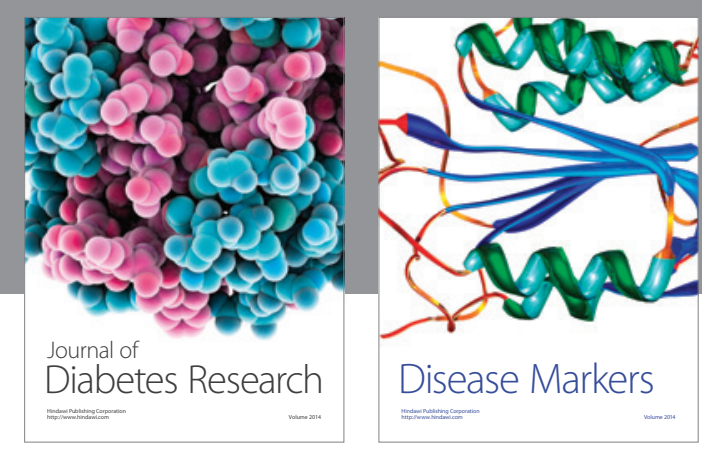

Disease Markers
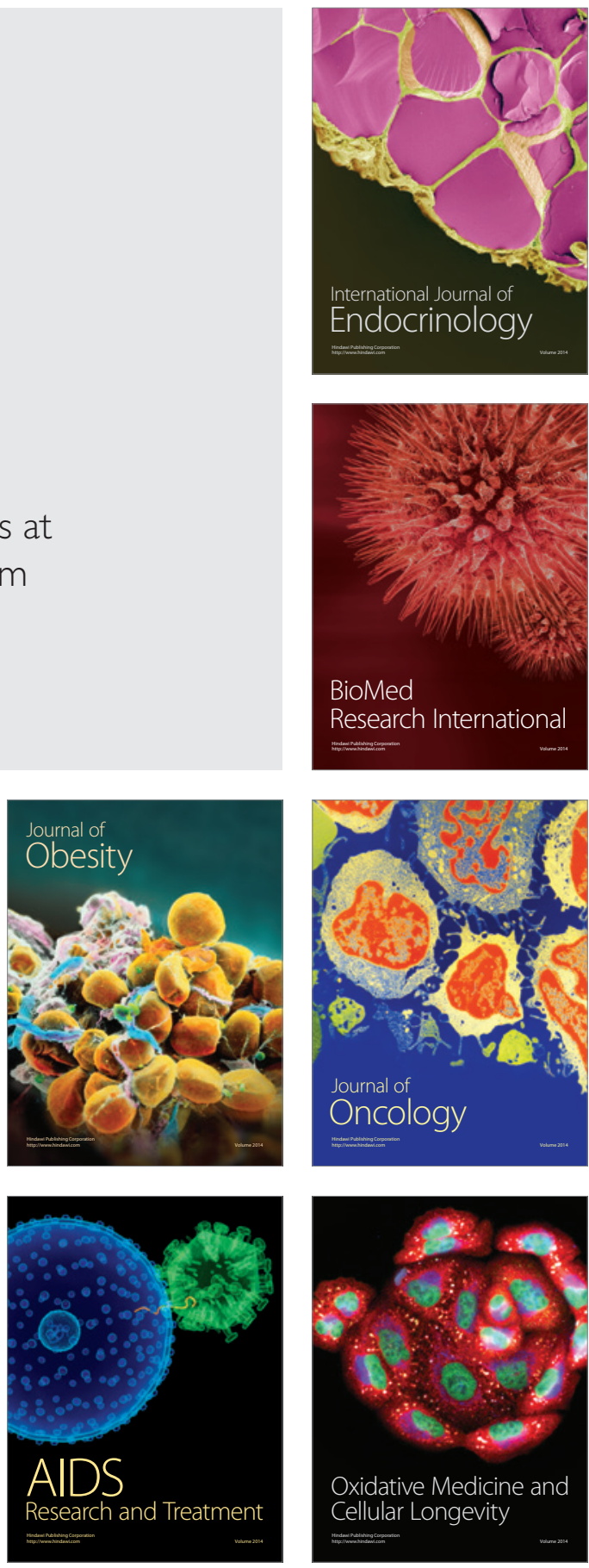